Western North American Naturalist 68(1), (C) 2008, pp. 58-65

\title{
THE CASE FOR HUMBOLDTENSIS: A SUBSPECIES NAME FOR THE INDIGENOUS CUTTHROAT TROUT (ONCORHYNCHUS CLARKII) OF THE HUMBOLDT RIVER, UPPER QUINN RIVER, AND COYOTE BASIN DRAINAGES, NEVADA AND OREGON
}

\author{
Patrick C. Trotter ${ }^{1}$ and Robert J. Behnke ${ }^{2}$
}

\begin{abstract}
In the early years of his research on the native trouts of western North America, Behnke (1960, 1966, 1979) observed consistent differences in certain meristic characters between the cutthroat trout of the Humboldt River drainage and those from the Truckee, Carson, and Walker river drainages of the Lahontan Basin, and proposed that the Humboldt trout be recognized as a distinct subspecies. He coined the subspecies name humboldtensis, but a formal description was never published. Here we again present the early evidence for subspecific distinction of the Humboldt drainage cutthroat trout, and add more recent findings from the fields of population genetics and Pleistocene and recent zoogeography that support this interpretation. Based on this evidence, we offer a formal description of the cutthroat subspecies Oncorhynchus clarkii humboldtensis and map its likely historical distribution. Available meristic and zoogeographic evidence indicates that the native trouts of the upper Quinn River, Nevada and Oregon and the Coyote Basin of Oregon should be included with humboldtensis as well.
\end{abstract}

Keywords: Humboldt cutthroat trout, Oncorhynchus clarkii humboldtensis, description, historical distribution, Humboldt River, Upper Quinn River, Coyote Basin, Lahontan Basin.

During the early years of his research on the native trouts of the genus Salmo (now Oncorhynchus) of western North America, Behnke (1960, 1966, 1979) found that specimens of cutthroat trout (Oncorhynchus clarkii) from the Humboldt River drainage on the east side of the Lahontan Basin in Nevada consistently differed in certain meristic characters from specimens from the Truckee, Carson, and Walker river drainages on the west side of the basin in California and Nevada. One difference was in lateral-series scale counts: 120-160 scales in the lateral series in Humboldt specimens versus 150-180 scales in the lateral series in Truckee, Carson, and Walker river specimens. But the major distinction was in the number of gill rakers: collections from Humboldt drainage populations consistently averaged $2-4$ fewer gill rakers $(\bar{x}=21)$ than populations from the Truckee, Carson, and Walker river drainages $(\bar{x}=24)$. Hickman (1978) also observed these consistent differences. As part of his study of the taxonomy of the native trout of the Bonneville Basin, Hickman (1978) developed a discriminate function computer analysis of 16 characters to quantify differences between Bonneville cutthroat trout $(O$. $c$. utah) and other cutthroat subspecies. When he included 35 specimens collected from the west side of the Lahontan Basin and 32 specimens collected from the Humboldt River drainage in this analysis, the program differentiated them with $100 \%$ accuracy.

The consistent difference in gill raker number is particularly significant in that having numerous gill rakers facilitates feeding on plankton in lakes (Martin and Sandercock 1967, McCart and Anderson 1967, Zaret 1980, McPhail 1984). This character is indicative of a lacustrine evolutionary history for trout of the Truckee, Carson, and Walker River drainages, most likely in association with pluvial Lake Lahontan into which these drainages discharged during the Pleistocene Epoch. The Humboldt River system also drained into Lake Lahontan during high stands of the pluvial lake, but the significantly lower number of gill rakers in the cutthroat trout of the Humboldt drainage points to a fluvial rather than lacustrine evolutionary history.

Based on the consistent differences in meristic characters and the distinctly separate evolutionary pathways implied by the differences in gill raker number, Behnke (1966) proposed 


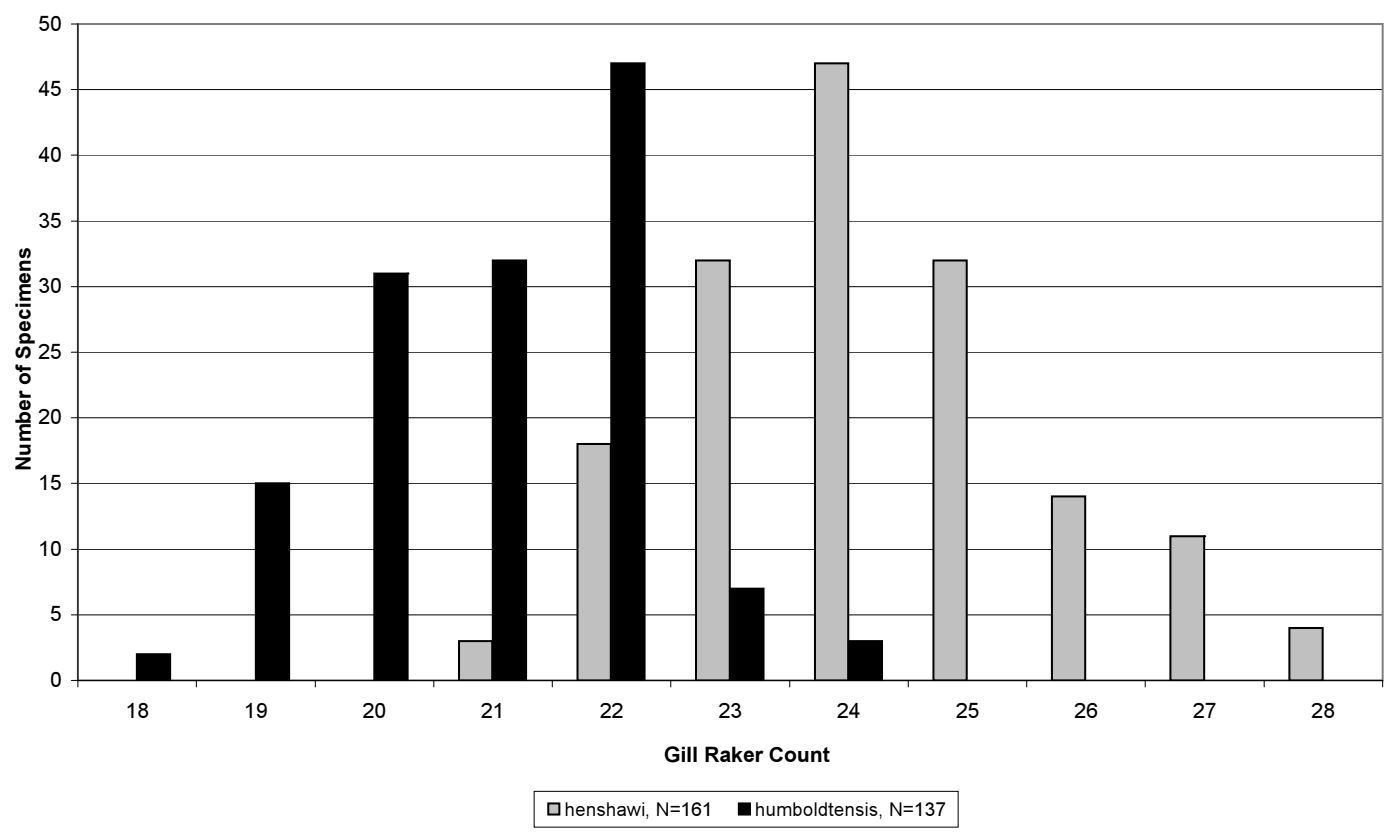

Fig. 1. Number of gill rakers in Oncorhynchus clarkii humboldtensis versus O. c. henshawi (data from Behnke 1966: table 8).

that the cutthroat trout of the Humboldt River drainage be recognized as a separate subspecies, humboldtensis, to distinguish it from the cutthroat trout of the Truckee, Carson, and Walker river drainages, which had already been described and named henshawi by Theodore N. Gill and David Starr Jordan in the 2nd edition of Jordan's Manual of the Vertebrates of the Northern United States (Jordan 1878) based on specimens from Lake Tahoe in the Truckee River drainage. Behnke originally coined the name humboldtensis in 1963 for a monograph, The Rainbow and Cutthroat Trouts of North America, that he had written with P.R. Needham that year. However, that monograph was withdrawn from the publication process in 1964 following Needham's death, so the name and formal description of the Humboldt subspecies were never published. Behnke used the name again for the Humboldt Basin subspecies in his doctoral dissertation (Behnke 1966), but as a nomen nudem ( $=$ a name without description), and in his subsequent publications (Behnke 1979, 1992, 2002), he opted to refer to the Humboldt cutthroat trout simply as an unnamed subspecies.

Here we reiterate Behnke's early evidence for the subspecific distinction of the Humboldt drainage cutthroat trout and add more recent findings that confirm his original interpretation. At this time we offer a formal description of the cutthroat subspecies humboldtensis and also a rationale for mapping its historical distribution to include not only the native cutthroat trout of the Humboldt River drainage of Nevada but also those of the upper Quinn River drainage of Nevada and Oregon and the Coyote Basin (also known in older publications as the Whitehorse Basin) of Oregon.

Behnke's (1960, 1966, 1979) comparisons of Humboldt drainage cutthroat trout with the cutthroat trouts of the Truckee, Carson, and Walker river drainages began with museum specimens collected by J.O. Snyder from 1911 to 1915 (see Snyder 1917) and continued with collections he made himself in 1961, 1962, 1963, and 1972. In total, Behnke's collections comprise more than 200 specimens from 27 localities all across the Humboldt River drainage. Figure 1 is a chart of gill raker counts of 137 Humboldt drainage specimens and 161 Truckee, Carson, and Walker river specimens from Behnke's 1961, 1962, and 1963 collections (data from Behnke 1966: table 8) that illustrates the distinct difference between the 2 sets of populations in just this 1 character. The 
humboldtensis data are left-skewed, with a mean value of 21 gill rakers and a mode of 22 . The henshawi data are just slightly rightskewed, with a mean of 24.2 gill rakers and a mode of 24. The null hypothesis that these distributions were drawn from the same overall population was rejected $(\alpha=0.05)$.

Although allozyme electrophoresis studies (Loudenslager and Gall 1980, Gall and Loudenslager 1981, Bartley et al. 1987, Williams 1991, Bartley and Gall 1993) have generally shown little variation within and among Lahontan Basin cutthroat populations, the study of Williams (1991) did find sufficient allozyme variation between Humboldt drainage populations and populations from the Truckee, Carson, and Walker river drainages to justify his conclusion that the 2 forms should be set apart from one another. Studies of mitochondrial DNA (mtDNA) variation (Williams and Shiozawa 1989, Williams 1991, Williams et al. 1992, 1998) also reveal small but significant differences among these populations. A molecular clock estimate based on these mtDNA sequence divergence data published by Smith et al. (2002) indicates that these forms have been separated for somewhere between 200,000 and 260,000 years. Studies of nuclear DNA variation (Nielsen and Sage 2002, Peacock and Kirchoff 2004) are even more convincing. Using $\mathrm{F}_{\mathrm{ST}}$, Nei's (1972) measure of genetic distance, these studies indicate that Humboldt cutthroat trout are as genetically distant from Truckee/Carson/ Walker drainage cutthroat trout as other cutthroat forms already recognized as distinct subspecies are from one another $\left(\mathrm{F}_{\mathrm{ST}}=0.496\right.$ in the Nielsen and Sage [2002] study; $\mathrm{F}_{\mathrm{ST}}=$ $0.530,0.597$, and 0.657 for 3 Humboldt drainage populations in the Peacock and Kirchoff [2004] study).

We believe that this evidence, when taken together with Behnke's evidence from meristic characters, supports recognition of the native trout of the Humboldt River drainage as a distinct subspecies, which we now name Oncorhynchus clarkii humboldtensis and describe as follows.

\section{Oncorhynchus clarkii humboldtensis}

Description.-Chromosomes, $2 \mathrm{~N}=64$. Scales in the lateral series, 117-160 (specimens from isolated headwater locations tend to have fewer scales than specimens from more open, downstream reaches), significantly fewer than in O. c. henshawi, which typically has 150-180 scales in the lateral series. Scales above the lateral line, 26-45. Gill rakers, 18-24 $(\bar{x}=21)$, significantly fewer than the $21-28(\bar{x}=24)$ typical of henshawi. Pyloric caeca numbers vary across the range but average 50-60 in most populations; however, the type specimen from the South Fork Little Humboldt River has 45 pyloric caeca, and trout native to Hanks Creek, a Mary's River tributary in the Humboldt drainage, average 65 pyloric caeca. Basibranchial teeth, 1-14, fewer than in most samples of other cutthroat subspecies. The type specimen has 11 basibranchial teeth. Body colors are generally dull in humboldtensis, a trait it shares with henshawi, and are typically brassy, coppery, or burnished silver with some tendency toward yellow. Rosy pink tints often appear on the sides and on the opercle. The ventral region is white to gray and the lower fins are typically brownish with sometimes pinkish tints. Two streaks of intense red or red-orange (the cutthroat marks) are displayed in the so-called hyoid grooves on either side of the lower jaws of specimens $\geq 100 \mathrm{~mm}$ in standard length. Oncorhynchus clarkii humboldtensis is regarded as a large-spotted cutthroat trout, as is henshawi, but spotting varies. The spots on humboldtensis are typically fewer than on henshawi and tend to be concentrated more on the posterior part of the body. Only rarely are spots found on the abdomen of humboldtensis, whereas they are often found on the abdomen of henshawi.

Type SPECimen (BehnKe's holotype).- an adult female $189 \mathrm{~mm}$ standard length, $220 \mathrm{~mm}$ total length; collected 16 July 1961 from the extreme headwaters of the South Fork Little Humboldt River approximately $8 \mathrm{~km}$ west of Midas, Elko County, Nevada, by Robert J. Behnke, John Schlechtweg (Behnke's young nephew who assisted in the field), and William Nisbet (Nevada Division of Wildlife). This specimen is preserved at the California Academy of Sciences, San Francisco, catalog number CAS 22561. Scales in lateral series (2 rows above lateral line), 128; scales above lateral line, 35. Gill rakers (on 1st left arch), $8+14=22$. Branchiostegal rays, 10 on both the left and right sides of the fish. Vertebrae, 61. Pyloric caeca, 45. Eleven basibranchial teeth. Pectoral fin rays, 14; pelvic fin rays, 9; dorsal fin, 10 principal rays; anal fin, 10 principal rays. 
Colors in life, burnished silvery background with golden olive hues and tints of rose along the sides and on the opercle; cutthroat marks distinct and bright red; fins drab olive-brown with lower fins tinged slightly pink. Spots are large and distinctly round on the caudal peduncle, but anterior spots are smaller and more irregularly shaped; a few tiny spots appear on the head above and posterior to the eye, and 2 distinct blotches appear on the cheek, the larger approximating the diameter of the pupil. Dorsal, adipose, and caudal fins are spotted, but the lower fins and abdomen are free of spots.

PARATYPES.-12 specimens ranging in standard length from $93 \mathrm{~mm}$ to $165 \mathrm{~mm}$ taken on the same date from the same location as the holotype and preserved together at the California Academy of Sciences, catalog number CAS 22562. This group has 20-24 gill rakers $(\bar{x}=21.6$, mode $=22)$; scales in lateral series, 121-138 $(\bar{x}=131)$; scales above lateral line, 30-39 $(\bar{x}=32)$. An additional 121 specimens collected in 1961, 1962, and 1963 from another 22 locations in the Humboldt River drainage are also preserved at the California Academy of Sciences, catalog numbers CAS 2256322584. Other specimens collected or acquired by Behnke after 1963, including specimens from 4 additional Humboldt drainage locations, are now in the ichthyology collection at Brigham Young University, Provo, Utah, but have not yet been cataloged. What remains of J.O. Snyder's original collections from the Humboldt River drainage between 1911 and 1915 (Snyder 1917) are housed at 2 institutions but are cataloged as henshawi. The Smithsonian National Museum of Natural History, Washington, DC, houses 14 of Snyder's specimens from 4 locations in the Humboldt drainage preserved in 4 groups, catalog numbers USNM 75709 (5 specimens), USNM 75710 (2 specimens), USNM 75712 (2 specimens) and USNM 75713 (5 specimens). The California Academy of Sciences, which acquired collections Snyder had originally deposited at Stanford University, has only a single Humboldt drainage specimen, collected from the Humboldt River near Carlin, Nevada, catalog number CAS 13308. Snyder himself examined only his specimens from Pyramid Lake and Lake Tahoe in the Truckee River drainage, and so never recognized the consistent differences in meristic characters between these trout and his Hum- boldt drainage specimens, later reported by Behnke (1960, 1966, 1979) and Hickman (1978).

\section{Discussion}

We believe humboldtensis is an appropriate subspecies name to highlight the importance of the Humboldt River drainage in hosting the evolution of a native cutthroat trout with 21 gill rakers-and, as we discuss below, for serving as the conduit for the spread of this form into the upper Quinn River drainage and thence to upper Coyote Basin streams in ancient times.

Our rationale for including the cutthroat trouts native to the upper Quinn River drainage of Nevada and Oregon and the cutthroat trouts of the Coyote Basin, Oregon, in humboldtensis is also based on meristic character counts and on geological evidence that the Humboldt River once took a northerly course to link with the upper Quinn River, a course it occupied throughout much of late Pleistocene time. With regard to the meristic character evidence, Behnke $(1979,1992)$ examined cutthroat trout specimens from Willow, Whitehorse, and Little Whitehorse creeks in the Coyote Basin, Oregon, that were collected at various times and by various workers from 1934 to 1972 . Williams (1991) also made meristic character counts of specimens collected later for allozyme and mtDNA analysis. These specimens also averaged 21 gill rakers, the same as the Humboldt cutthroat trout, and 131-164 lateral-series scales (population averages ranged from 147 to 150), also the same as the Humboldt cutthroat trout. Specimens from upper Quinn River tributaries were not examined by Behnke, but he did report that data given him indicated that gill raker counts averaged 20-21 for these specimens as well (Behnke 1992). Unfortunately, we cannot confirm these Quinn River numbers at this time, as we have not been able to locate Behnke's original source for this information or the original data sheets; nor has there been any opportunity to reexamine preserved specimens from the Quinn River drainage. Specimens collected by Snyder (1917) from 2 locations in the Quinn River drainage were either never deposited or were not retained by the institutions presently housing his collections, but specimens collected later for allozyme and mtDNA analysis, referred to by Williams (1991), may still be present in the Brigham Young University collection. 


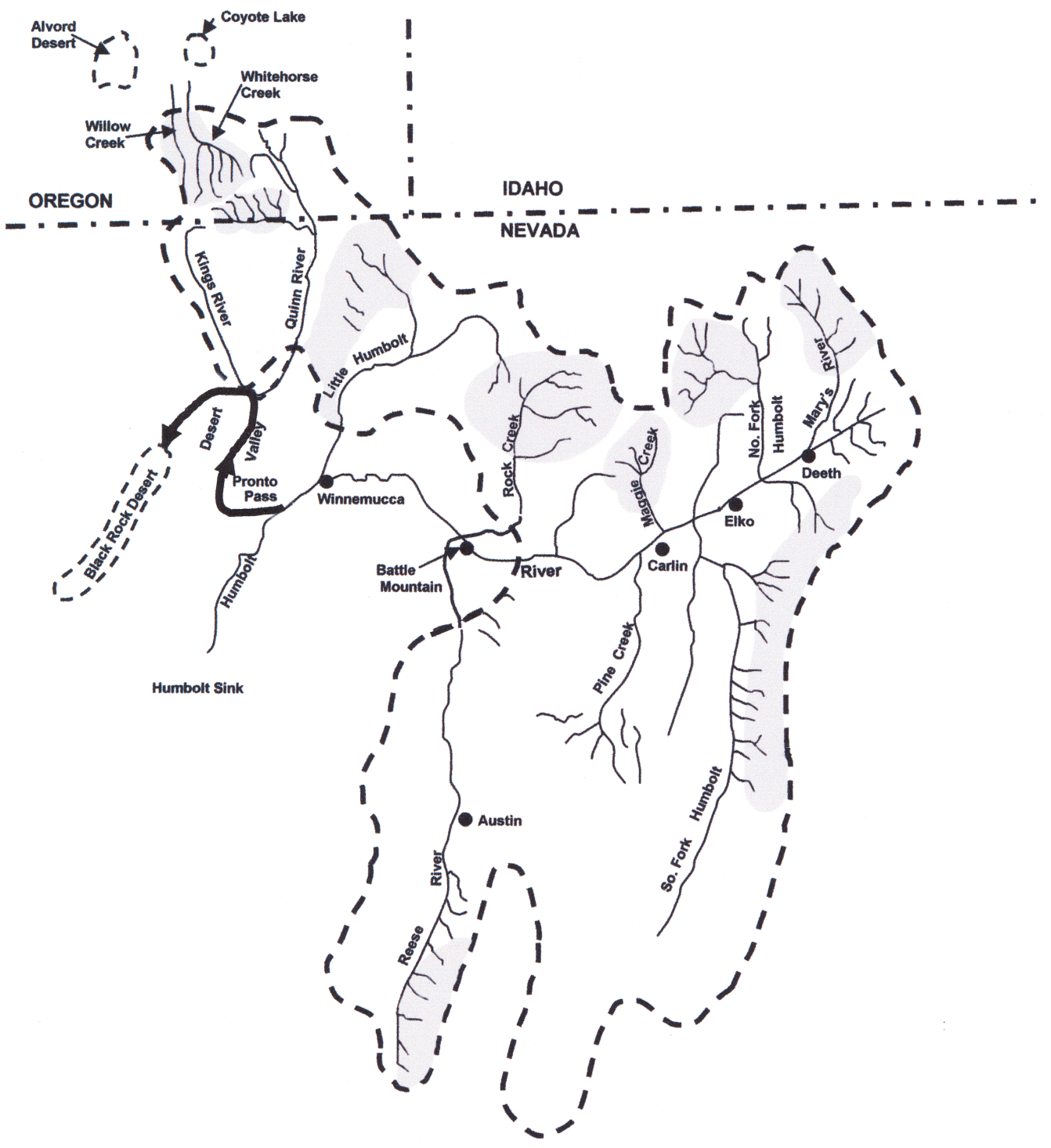

$\longrightarrow$ Areas where humboldtensis populations may persist.

- Probable extent of historical distribution.

Probable northward course of Humboldt River during Pleistocene interpluvial periods between 600,000 and 700,000 years ago to about 12,000 years ago. Quinn and King's rivers were tributaries of the Humboldt River during these periods.

Courses of rivers and tributaries today. (Lower reaches of some streams are intermittent.)

Fig. 2. Postulated historical distribution of Oncorhynchus clarkii humboldtensis.

Although Behnke initially set the cutthroat trout of the Coyote Basin apart as their own unnamed subspecies (Behnke 1979), he later interpreted the evidence as suggesting a northward gradation of characters from the Hum- boldt River to the upper Quinn River to the Coyote Basin and a common origin for their indigenous trouts (Behnke 1992, 2002), thus placing them with humboldtensis as we do here. The zoogeographic evidence supporting 
this view is illustrated in Figure 2, which maps what we now believe to be the likely extent of the historical distribution of $O . c$. humboldtensis (i.e., distribution at the time of 1st contact in American history with trappers, explorers, and settlers of largely European extraction), with the indigenous Quinn River and Coyote Basin cutthroat trouts included. Focus your attention on the Humboldt River downstream from the present city of Winnemucca, Nevada. There, a string of bold arrows traces an ancient Humboldt channel westward through Pronto Pass and then north through Desert Valley to intersect the upper Quinn River. The combined waters of this ancient Humboldt/ Quinn River then flowed southwesterly to the Black Rock Desert, which acted as a sink for its waters during interpluvial periods. Available evidence (Davis 1982, 1990, Benson and Peterman 1995, Adams et al. 1999) indicates that this ancient channel may have existed from the mid-Pleistocene, 600,000-700,000 years ago, to the end of the Pleistocene Epoch, about 10,000 years ago, when the Humboldt River cut its present waterway with flowage thereafter toward the Humboldt Sink. This ancient and long-standing Humboldt/Quinn connection undoubtedly accounts for the presence of the fluvially evolved cutthroat trout averaging 21 gill rakers in the Humboldt River drainage well upstream from pluvial Lake Lahontan and also in the upper Quinn River watershed. Headwater tributaries of the Quinn River originate in the Trout Creek Mountains in southeastern Oregon, very close to the headwaters of the Whitehorse and Willow Creek drainages of the Coyote Basin, making the Quinn River the likely source of the Coyote Basin trout via interbasin transfer (Behnke 1992).

Although allozyme and mtDNA results reported by Williams (1991) and Williams et al. (1992, 1998) appear to place both the upper Quinn River and Coyote Basin cutthroat trouts with henshawi rather than with humboldtensis, we believe these findings can be explained by (1) secondary contact during pluvial high stands of Lake Lahontan and/or (2) early, widespread stocking of cutthroat trout of Truckee River origin into upper Quinn River tributaries. Regarding the 1st point, the most recent chronology available for pluvial Lake Lahontan (Reheis and Morrison 1997, Reheis et al. 2002) dates its highest stand as occurring about 650,000 years ago. High stands that occurred around 180,000 to 130,000 years ago and again around 35,000 to 12,000 years ago (the most recent high stand) were lower, but still were high enough to reconnect the ancient Humboldt/ Quinn river system with the pluvial lake. These reconnections provided opportunities for lacustrine-associated trout populations to exchange genetic material with the fluvial trouts of at least the lower portion of the Humboldt/ Quinn system, which may account for the similarities reported by Williams (1991) and Williams et al. (1992, 1998) in present-day mtDNA haplotypes. As for the 2 nd point, Sevon et al. (1999) stated that between 1905 and 1925, 190,000 "blackspotted trout" were planted in streams of Humboldt County, Nevada, which includes Nevada's portion of the upper Quinn River system. These trout originated from Pyramid Lake stock obtained from the Truckee River and may also have contributed to the mtDNA makeup of present-day populations.

When the U.S. Endangered Species Act became law in 1973, O. c. henshawi was 1 of 3 subspecies of cutthroat trout that were listed, first as endangered and then later, to facilitate management, as threatened. Since late 1991, the U.S. Fish and Wildlife Service and the state fish and game agencies of Nevada and Oregon have lumped all cutthroat trouts of the Lahontan and Coyote basins together as the single subspecies O. c. henshawi, even though the formal description of henshawi was based only on the trouts of the Truckee, Carson, and Walker river drainages. However, in acknowledgement of the meristic, genetic, and ecological differences that do exist among these populations, the agencies did divide them into 3 distinct population segments (DPSs) for purposes of management and recovery activities. Thus, the Western Lahontan Basin DPS includes all native cutthroat populations of the Truckee, Carson, and Walker river drainages; the Humboldt River Basin DPS encompasses the native cutthroat populations of the Humboldt River drainage; and the Northwestern Lahontan Basin DPS includes the cutthroat trouts of the upper Quinn River and other Black Rock Desert streams, as well as those of the Coyote Basin (Coffin and Cowan 1995).

This is all well and good for fishery management and recovery purposes under the Endangered Species Act-and we do agree that 
all Lahontan Basin and Coyote Basin cutthroat trout populations remain in serious need of protection under the Endangered Species Act regardless of their taxonomic classification. Nevertheless, we argue that lumping the Humboldt, upper Quinn, and Coyote Basin populations in with those of the Truckee, Carson, and Walker drainages as henshawi fails to recognize the separate evolutionary pathways followed by the 2 sets of populations, as well as their long separation. This is corrected by recognizing the native cutthroat trouts of the Humboldt River, upper Quinn River, and Coyote Basin as the distinct subspecies O. c. humboldtensis.

\section{ACKNOWLEDGMENTS}

We thank Dennis Shiozawa, Brigham Young University, Provo, Utah; Dave Catanio, California Academy of Sciences, Department of Ichthyology, San Francisco; and the staff at the Smithsonian Institution National Museum of Natural History, Department of Vertebrate Zoology, Division of Fishes, Washington, DC, for information about the Lahontan Basin cutthroat trout specimens preserved in their collections. We also thank Rena Langille for preparing the map that appears in Figure 2. Thanks go also to Dennis Shiozawa for helpful early discussions and to 2 anonymous reviewers whose comments on our draft manuscript helped us improve this paper.

\section{Literature Cited}

ADAMS, K.D., S.G. Wesnousky, AND B.G. BiLls. 1999. Isostatic rebound, active faulting, and potential geomorphic effects in the Lake Lahontan basin, Nevada and California. Geological Society of America Bulletin 111:1739-1756.

BarTLEY, D.M., AND G.A.E. GaLL. 1993. Genetic analysis of threatened Nevada trout: report on populations collected from 1988-1992. Report on Contract 86-98 to Nevada Department of Wildlife. Fisheries Biology Research Facility, Department of Animal Sciences, University of California, Davis. 23 pp.

Bartley, D.M., G.A.E. Gall, and A. Marshall-Ross. 1987. Biochemical genetic analysis of Nevada trout populations, October 1987. Report to Nevada Department of Wildlife. Fisheries Biology Research Facility, Department of Animal Sciences, University of California, Davis.

BehnKe, R.J. 1960. Taxonomy of the cutthroat trout of the Great Basin with notes on the rainbow series. Master's thesis, University of California, Berkeley. $98 \mathrm{pp}$ .1966. A systematic study of the family Salmonidae with special reference to the genus Salmo. Doctoral dissertation, University of California, Berkeley [Uni- versity Microfilms International, Ann Arbor, MI, 1981].

1979. Monograph of the native trouts of the genus Salmo of western North America. USDA Forest Service, U.S. Fish and Wildlife Service, and Bureau of Land Management, Fort Collins, CO. 215 pp.

1992. Native trout of western North America. American Fisheries Society Monograph 6, Bethesda, MD. 275 pp.

2002. Trout and salmon of North America. The Free Press, New York. 359 pp.

Benson, L.V., and Z. Peterman. 1995. Carbonate deposition, Pyramid Lake Subbasin, Nevada: 3. The use of ${ }^{87} \mathrm{Sr}$ values in carbonate deposits (tufas) to determine the hydrologic state of paleolake systems. Paleogeography, Paleoclimatology, Paleoecology 119:201213.

Coffin, P.D., AND W.F. Cowan. 1995. Lahontan cutthroat trout (Oncorhynchus clarki henshawi) recovery plan. U.S. Fish and Wildlife Service, Region 1, Portland, OR. 108 pp. +7 appendixes.

DAVIS, J.O. 1982. Bits and pieces: the last 35,000 years in the Lahontan area. Pages 53-75 in D.B. Madsen and J.F. O'Connell, editors, Man and environment in the Great Basin. Society for American Archaeology, SAA Papers 2, Washington, DC.

1990. Giant meanders on Humboldt River near Rye Patch, Nevada, due to catastrophic flooding. Geological Society of America Abstracts with Programs 22, no. 6: A3097.

Gall, G.A.E., And E.J. Loudenslager. 1981. Biochemical genetics and systematics of Nevada trout populations. Final Report to Nevada Department of Wildlife. Fisheries Biology Research Facility, Department of Animal Sciences, University of California, Davis. $53 \mathrm{pp}$.

Hickman, T.J. 1978. Systematic study of the native trout of the Bonneville Basin. Master's thesis, Colorado State University, Fort Collins. 122 pp.

JoRDAn, D.S. 1878. Manual of the vertebrates of the northern United States, including the district east of the Mississippi River, and north of North Carolina and Tennessee, exclusive of marine species. 2nd edition. Jansen, McClurg \& Company, Chicago, IL.

Loudenslager, E.J., And G.A.E. Gall. 1980. Geographic patterns of protein variation and subspeciation in cutthroat trout, Salmo clarki. Systematic Zoology 29:27-42.

Martin, N.V., and F.K. Sandercock. 1967. Pyloric caeca and gill raker development in lake trout, Salvelinus namaycush, in Algonquin Park, Ontario. Journal of the Fisheries Research Board of Canada 24:965-974.

MCCART, P., AND B. ANDERSON. 1967. Plasticity of gill raker number and length in Oncorhynchus nerka. Journal of the Fisheries Research Board of Canada 24:1999_ 2002.

McPhaIL, J.D. 1984. Ecology and evolution of sympatric sticklebacks (Gasterosteus): morphological and genetic evidence for a species pair in Enos Lake, British Columbia. Canadian Journal of Zoology 62:14021408.

NEI, M. 1972. Genetic distance between populations. American Naturalist 106:283-292.

Nielsen, J.L., AND G.K. SAge. 2002. Population genetic structure in Lahontan cutthroat trout. Transactions of the American Fisheries Society 131:376-388.

Peacock, M.M., and V. Kirchoff. 2004. Assessing the conservation value of hybridized cutthroat trout 
populations in the Quinn River drainage, Nevada. Transactions of the American Fisheries Society 133 309-325.

Reheis, M.C., and R.B. Morrison. 1997. High, old pluvial lakes of western Nevada. Pages 459-492 in P.K. Link and B.J. Kowallis, editors, Proterozoic to Recent stratigraphy, tectonics, and volcanology, Utah, Nevada, southern Idaho, and central Mexico. Brigham Young University Geology Studies 42, part 1, Provo, UT.

Reheis, M.C., A.M. Sarna-Wojcicki, R.L. Reynolds, C.A. Repenning, and M.D. Mifflin. 2002. Pliocene to Middle Pleistocene lakes in the western Great Basin: ages and connections. Pages 53-108 in R. Hershler, D.B. Madsen, and D. Currey, editors, Great Basin aquatic systems history. Smithsonian Contributions to the Earth Sciences, No. 33, Smithsonian Institution Press, Washington, DC.

Sevon, M., J. French, J. Curran, and R. Phenix. 1999. Lahontan cutthroat trout management plan for the Quinn River/Black Rock basins and North Fork Little Humboldt River sub-basin. Federal Aid Project F-20-27, Job 113-P, Nevada Division of Wildlife, Reno. 43 pp. +4 appendixes.

Smith, G.R., T.E. Dowling, K.W. Gobalet, T. Lugaski, D.K. ShIozaWa, and R.P. Evans. 2002. Biogeography and timing of evolutionary events among Great Basin fishes. Pages 175-234 in R. Hershler, D.B. Madsen, and D. Currey, editors, Great Basin aquatic systems history. Smithsonian Contributions to the Earth Sciences, No. 33, Smithsonian Institution Press, Washington, DC.
SNYDER, J.O. 1917. Fishes of the Lahontan system of Nevada and northeastern California. U.S. Bureau of Fisheries Bulletin 35:33-86.

WiLLiams, R.N. 1991. Genetic analysis and taxonomic status of cutthroat trout from Willow Creek and Whitehorse Creek in southeastern Oregon. Evolutionary Genetics Laboratory, Report 91-3. Boise State University, Boise, ID. 15 pp.

Williams, R.N., R.P. Evans, and D.K. Shiozawa. 1998. Genetic analysis of indigenous cutthroat trout populations from northern Nevada. Clear Creek Genetics Lab Report 98-1 to Nevada Department of Wildlife, Reno.

Williams, R.N., and D.K. Shiozawa. 1989. Taxonomic relationships among cutthroat trout of the western Great Basin: conservation and management implications. Oregon Trout Technical Report No. 1. Oregon Trout, Portland, OR. 19 pp.

Williams, R.N., D.K. ShiozaWa, and R.P. Evans. 1992. Mitochondrial DNA analysis of Nevada cutthroat trout populations, 25 August 1992. Evolutionary Genetics Laboratory, Report 91-5. Boise State University, Boise, ID. $27 \mathrm{pp}$.

ZaReT, T.M. 1980. Predation and freshwater communities. Yale University Press, New Haven, CT. 187 pp.

Received 29 May 2007 Accepted 10 October 2007 